\title{
The First Metacarpal is the Thumb First Phalange. EvoDevo Implications
}

\author{
El Primer Metacarpiano es la Primera Falange del Pulgar. Implicaciones en EvoDevo
}

"Carlos, Y. Valenzuela; "**Bríos-Loyola, R. \& ** Canals, M.

CARLOS Y VALENZUELA, C. Y.; BERRÍOS-LOYOLA, R. \& CANALS, M. The first metacarpal is the thumb first phalange. EvoDevo implications. Int. J. Morphol., 27(4):985-988, 2009.

SUMMARY: We examined the status of the first metacarpal bone whose shape, fetal and post-natal development correspond to those of the thumb proximal phalanx. Galen already described this, circa $170 \mathrm{CE}$. Our radiographic data confirm that the pre-axial (radial or anterior) side of the hand matures, later than the post-axial (ulnar or posterior) side, both, pre- and post-natally. A new perspective on thumb primate and human ontogeny is discussed and comparative observations on the Evolutionary Development (EvoDevo) of the thumb and the first toe are proposed along with a nomenclature honoring Galen's original proposition.

KEY WORDS: Bone maturity; Thumb EvoDevo; First metacarpal; Thumb's first phalanx.

\section{INTRODUCTION}

Our longitudinal follow-up study of Chilean children confirms that the ossification pattern of the first metacarpal bone (MC-I) follows rather the ossification pattern of a phalanx (Patri et al., 1984; Avendaño \& Valenzuela, 1988; Canals et al., 1985, 1986, 1988, 1993; Valenzuela et al., 1985; Valenzuela \& Canals, 1988), a well-known fact in pediatric radiology. Metacarpal epiphyses (II, III, IV and V) ossify postnatally at the distal extremity, but MC-I ossification occurs at its proximal extremity just as a phalanx (Greulich \& Pyle, 1959; Tanner $e t$ al., 1975; Canals at al., 1993). However, this disagreement has not influenced the Nomina Anatomica (Feneis, 1984; Aiello \& Dean, 2002; Prochel et al., 2004), even though it was proposed by Galen, circa 170 AD (Testut \& Latarjet, 1969). Pediatric radiology indicates that the radial carpus (trapezium, trapezoid and scaphoid) is delayed in maturation in relation to the ulnar carpus (hamate, triquetral and lunate). The aim of this article is to confirm these traits of the human carpus with population data and suggest an evolutionary new approach.

\section{SAMPLE AND METHOD}

The samples belong to two longitudinal follow-up studies of Chilean male and female newborns, infants, children and adolescents. The first study included infants and children from 0 to 6 years of age (Patri et al.), and the second, 5 to 20 year old children and adolescents (Avendaño \& Valenzuela). Periodical radiographies of wrist and hand were performed to assess skeletal maturity. Bone maturity stages were calculated according to the TW20 method (Tanner et al.). Parameters of the age at which $50 \%$ of the population showed a defined stage were estimated by the probit method (Valenzuela et al.; Valenzuela \& Canals). When there were two parameter values for the same stage, one from the first, and another from the second study, a weighted estimate was calculated. Other methodological details are mentioned in the original articles. These data were published to provide the pediatrician for standards of bone development in Chilean children. In this article, they are seen from an evolutionary and developmental perspective.

\section{RESULTS}

Tables I and II show, for males and females, respectively, the mean age at which $50 \%$ of the population reach the maturing stages, according to the ulnar or radial edge of carpal, metacarpal and first phalanx bones.

\footnotetext{
* Programa de Genética Humana, ICBM, Facultad de Medicina, Universidad de Chile, Santiago, Chile.

** Departamento de Ciencias Ecológicas, Facultad de Ciencias, Universidad de Chile, Santiago, Chile.
} 
Table I. Age in months at which $50 \%$ of the male population attain the maturing stages. $5^{\circ}$ Phal Prox $=5^{\circ}$ proximal phalanx.

\begin{tabular}{|c|c|c|c|c|c|c|c|c|}
\hline \multicolumn{9}{|c|}{ Males } \\
\hline \multicolumn{9}{|c|}{ Ulnar edge bones } \\
\hline & B & $\mathrm{C}$ & $\mathrm{D}$ & $\mathrm{E}$ & $\mathrm{F}$ & $\mathrm{G}$ & $\mathrm{H}$ & I \\
\hline $5^{\circ}$ Prox Phal & 27.2 & 29.9 & 37.5 & 63.4 & 134.1 & 160.5 & 185.8 & 197.1 \\
\hline $5^{\circ}$ Metacarpal & 29.5 & 34.7 & 45.3 & 67.9 & 120.4 & 155.6 & 189.8 & 196.8 \\
\hline Hamate & & -6.0 & 37.1 & 54.9 & 73.9 & 116.7 & 145.9 & 164.0 \\
\hline Triquetral & 34.9 & 43.6 & 60.8 & 81.4 & 114.7 & 139.4 & 162.1 & ---- \\
\hline Lunate & 57.5 & 64.0 & 80.3 & 98.4 & 124.8 & 146.6 & 168.8 & ---- \\
\hline \multicolumn{9}{|c|}{ Radial edge bones } \\
\hline $1^{\circ}$ Prox Phal & 36.8 & 48.8 & 54.2 & 83.8 & 130.8 & 164.0 & 192.4 & 204.0 \\
\hline $1^{\circ}$ Metacarp & 36.4 & 46.6 & 61.7 & 98.9 & 134.0 & 157.9 & 177.5 & 204.0 \\
\hline Trapezium & 78.7 & 90.7 & 88.7 & 106.2 & 123.9 & 144.4 & 160.9 & 179.9 \\
\hline Trapezoid & 75.5 & 81.2 & 89.0 & 101.4 & 120.9 & 142.7 & 159.9 & ---- \\
\hline S caphoid & 71.9 & 82.6 & 89.7 & 104.7 & 124.4 & 145.4 & 172.2 & ---- \\
\hline
\end{tabular}

Table II. Age in months at which $50 \%$ of the female population attain the maturing stages

\begin{tabular}{|c|c|c|c|c|c|c|c|c|}
\hline \multicolumn{9}{|c|}{ Females } \\
\hline \multicolumn{9}{|c|}{ Ulnar edge bones } \\
\hline & B & $\mathrm{C}$ & $\mathrm{D}$ & $\mathrm{E}$ & $\mathrm{F}$ & G & $\mathrm{H}$ & I \\
\hline $5^{\circ}$ Prox Phal & 17.1 & 19.6 & 26.0 & 44.2 & 106.3 & 129.4 & 154.4 & 172.4 \\
\hline $5^{\circ}$ Metacarpal & 18.2 & 23.3 & 32.4 & 54.7 & 105.7 & 130.7 & 161.7 & 177.0 \\
\hline Hamate & & -2.6 & 27.3 & 40.4 & 62.3 & 96.8 & 118.5 & 139.3 \\
\hline Triquetral & 26.3 & 32.4 & 46.9 & 62.5 & 98.7 & 114.9 & 134.3 & ---- \\
\hline Lunate & 42.1 & 48.7 & 63.1 & 75.3 & 106.2 & 125.2 & 149.6 & ---- \\
\hline \multicolumn{9}{|c|}{ Radial edge bones } \\
\hline $1^{\circ}$ Prox Phal & 27.2 & 32.8 & 35.6 & 60.2 & 107.1 & 130.9 & 161.6 & 174.2 \\
\hline $1^{\circ}$ Metacarp & 23.4 & 28.6 & 42.3 & 76.5 & 108.9 & 128.6 & 152.9 & 176.0 \\
\hline Trapezium & 50.6 & 57.4 & 60.3 & 78.1 & 97.2 & 118.4 & 132.7 & 159.1 \\
\hline Trapezoid & 55.1 & 62.2 & 66.6 & 76.6 & 99.1 & 120.0 & 140.3 & ---- \\
\hline S caphoid & 53.1 & 60.6 & 69.0 & 82.4 & 101.1 & 120.5 & 152.4 & ---- \\
\hline
\end{tabular}

Females mature earlier than males; the exception is the hamate at stage $\mathrm{C}$ for which the negative values indicate that intrauterine maturing occurs earlier in males. It is also evident that post-axial (ulnar) bones mature earlier than preaxial (radial) bones. In both edges and sexes the proximal phalanx bone develops at similar ages as the metacarpal bone.

\section{DISCUSSION}

It is evident from developmental features that MC-I maturates postnatally as a Phalanx. However, this picture seen among anthropoids is a relict of a more complex pattern of maturation. In phylogeny, the pattern with only one end of ossification (distal for MC-II-III-IV-V and proximal for MC-I) is found in mammals Eutheria and Metatheria (marsupials); Prototheria mammals (Monotremes) show two ossification ends (OE) at the five MC bones, and most nonmammalian tetrapods show often two $\mathrm{OE}$ at the five $\mathrm{MC}$ and phalanges (Reno et al., 2007). Thus, our proposition may be contra-argued from these evolutionary developmental (EvoDevo) findings. The delayed maturation of the radial carpal bones, where the thumb and its joint with the trapezium articulation are found, could be due to adaptive neoteny to a more complex function. Thus, MC I could be the Trapezium shortened by selection to function as a new evolutionary adaptation. However, these hypotheses should be taken critically, because the Radius' ossification occurs earlier than the ulnar's ossification. Also, in the foot, the pre-axial (tibial) bones mature later than the post-axial (fibular) tarsal and metatarsal bones, while the Tibia matures earlier than the Fibula (Vogt \& Vickers, 1931; Newell-Morris \& Tarrant, 1978). From an evolutionary viewpoint the first toe lost functions with bipedalism. The fine heterochrony of the foot and hand deserves future research. We do not intend such a fine and exhaustive analysis, but simply to emphasize the evidence that shows nomenclature inconsistency and to look at EvoDevo of the hand and foot from a fresh and older perspective. 


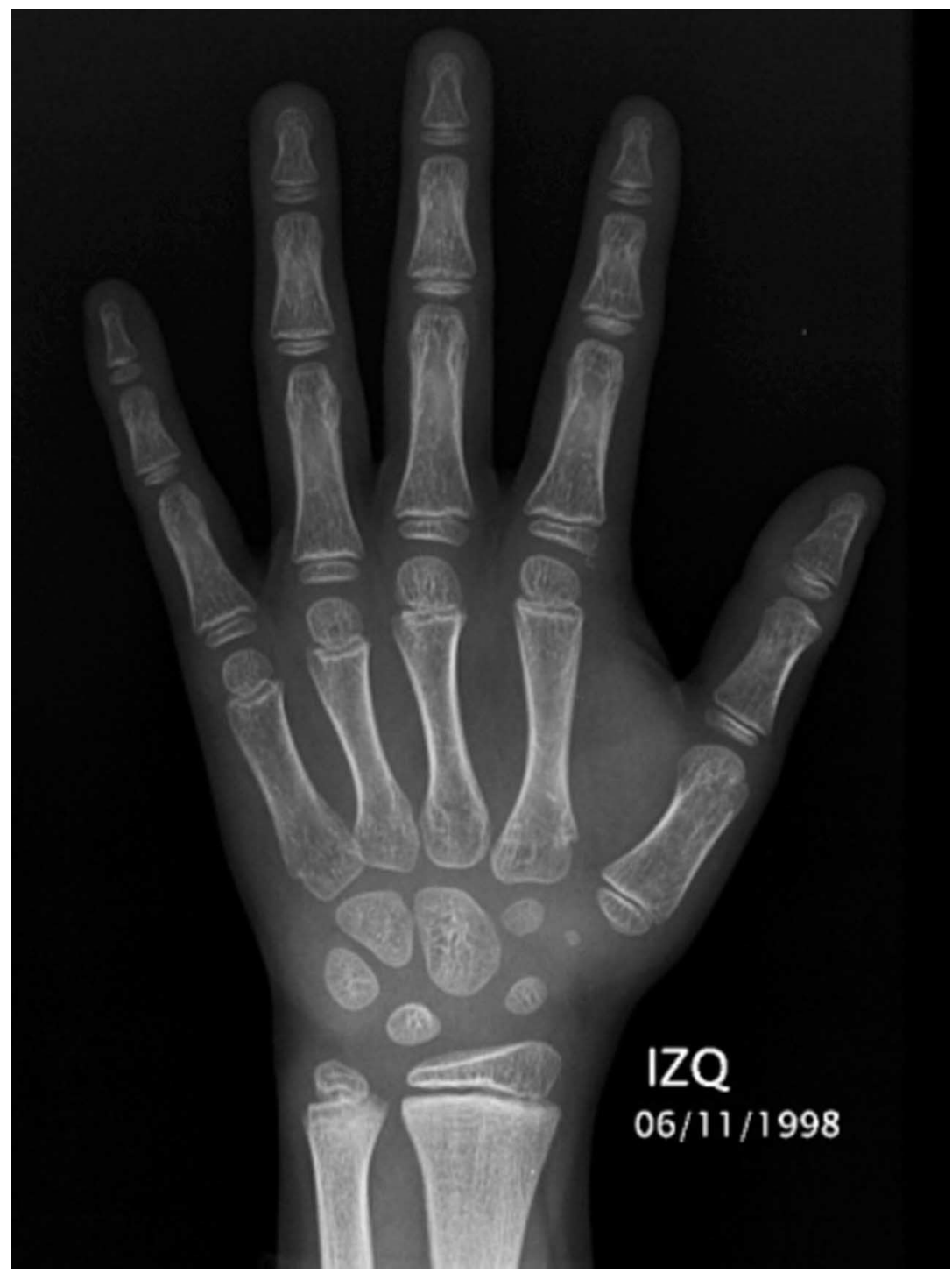

Fig. 1. Radiography of the left hand and wrist of a 9 years old boy. Metacarpal I (corresponding to the thumb) has a proximal point of ossification as the other phalanges have. Metacarpal II, III, IV and $\mathrm{V}$ have distal point of ossification. The radial carpal bones are less ossified than the ulnar carpal bones. The ossification of the radial distal epiphysis is more advanced than the ulnar distal epiphysis.

\section{ACKNOWLEDGEMENTS}

Prof. Edgardo Hidalgo improved our vision of the metacarpal and thumb joints functions. Hospital Roberto del Río and Hospital Clínico de la Universidad de Chile gave us information on bone maturing from their files; the latter provided us Fig. 1.

CARLOS Y VALENZUELA, C. Y.; BERRÍOS-LOYOLA, R. \& CANALS, M. El primer metacarpiano es la primera falange del pulgar. Implicaciones en EvoDevo. Int. J. Morphol., 27(4):985-988, 2009.

RESUMEN: Se analiza el estado del primer metacarpiano cuya forma y desarrollo embrionario, fetal y postnatal corresponde a los de la primera falange del pulgar. Galeno notó que éste era la primera falange del pulgar cerca de 170 DC. Esto no es un simple cambio de nomenclatura, ya que da una nueva luz a los problemas evolutivos de ontogenia (EvoDevo). Nuestros datos radiográficos confirman que el lado radial (anterior o pre-axial) de la mano madura, pre y post-natalmente, mas tardíamente que el lado cubital (posterior o postaxial). Se discuten nuevas perspectivas sobre la ontogenia y filogenia humana y de primates, y se proponen estudios comparativos del desarrollo del pulgar y del ortejo mayor.

PALABRAS CLAVE: Madurez ósea; Pulgar EvoDevo; Primer metacarpiano; Primera falange del pulgar.

\section{REFERENCES}

Aiello, L. \& Dean, C. Human evolutionary anatomy. San Diego, CA, Academic Press, 2002.
Avendaño, A. \& Valenzuela, C. Y. Seguimiento longitudinal de crecimiento y desarrollo 6 a 20 años de edad. Área 
Norte de Santiago. Pediatría (Santiago), 31:4-58, 1988.

Canals, M.; Valenzuela, C. Y. \& Vergara, P. Maduración ósea de niños de 0 a 6 años. Muñeca y mano. I Parte. Análisis cuantitativo. Rev. Chil. Pediatr., 56:325-8, 1985.

Canals, M.; Valenzuela, C. Y. \& Vergara, P. Maduración ósea de niños de 0 a 6 años. Muñeca y mano. III. Comparación de muestras y Métodos de evaluación. Rev. Med. Chile., 114:419-24, 1986.

Canals, M. L.; Valenzuela, C.Y.; Avendaño, A. \& Samith, S. Maduración ósea de niños mayores de 6 años. Muñeca y mano. I Parte: Análisis Cuantitativo. Rev. Chil. Pediatr., 59:102-5, 1988.

Canals, M.; Valenzuela, C. Y. \& Avendaño, A. Atlas de la madurez ósea. Santiago, Chile, Editorial Mediterráneo, 1993.

Feneis, H. Nomenclatura anatómica ilustrada. Barcelona, España, Salvat, 1984.

Gilbert, S. F. Developmental Biology. $7^{\circ}$ Ed. Sunderland, M.A., Sinauer, 2003.

Greulich, W. W. \& Pyle, S. I. Radiographic atlas of skeletal development of the hand and wrist. Stanford, CA., Stanford University Press, 1959.

Newell-Morris, L. \& Tarrant, L. H. Ossification in the hand and foot of the macaque (Macaca nemestrina). Am. J. Phys. Anthrop., 48:441-54, 1978.

Patri, A.; Sepúlveda, H.; Valenzuela, C. Y. \& Cortés, O. Antropometría del niño Chileno de 0 a 6 años. Santiago, Chile, Editorial Andrés Bello, 1984.

Prochel, J.; Vogel, P. \& Sánchez-Villagra, M. R. Hand development and sequence of ossification in the forelimb of the European shrew Crocidura russula (Soricidae) and comparisons cross therian mammals. J. Anat., 205:99-111, 2004.

Reno, P. L.; Horton, W. L.; Elsey, R. M. \& Lovejoy, C. O. Growth plate formation and development in alligator and mouse metapodials: evolutionary and functional implications. J. Exp. Zool., 308B:283-96, 2007.

Tanner, J.M.; Whitehouse, R. H.; Marshall, W. A.; Healy, M. J. R. \& Goldstein, H. Assessment of skeletal maturity and prediction of adult height (TW2 Method). London, Academic Press, 1975.
Testut, L. \& Latarjet, A. Tratado de Anatomía Humana. Barcelona, España, Salvat Editores. S. A., 1966.

Valenzuela, C. Y.; Canals, M. \& Vergara, P. Maduración ósea de niños de 0 a 6 años. II Parte. Análisis de probitos para huesos aislados. Rev. Chil. Pediatr., 56:329-33, 1985.

Valenzuela, C. Y. \& Canals, M. L. Maduración ósea de niños de 6 a 19 años. Muñeca y Mano. II Parte. Análisis de probitos para huesos aislados. Rev. Chil. Pediatr., 59:178-82, 1988.

Vogt, E. C. \& Vickers, V. S. Osseous growth and development. Radiology, 31:441-4, 1931.

Correspondence to:

Carlos Y. Valenzuela

Programa de Genética Humana, ICBM

Facultad de Medicina, Universidad de Chile

Independencia 1027, Casilla 70061, Independencia

CHILE

FAX (56-2) 7373158

Phone (56-2) 9786302

Email: cvalenzu@med.uchile.cl

Received: 03-08-2009

Accepted: 05-09-2009 